\title{
Destripeptide Insulin-Like Growth Factor-I in Milk from Bovine Somatotropin-Treated Cows
}

\author{
GRANT T. SHIMAMOTO ${ }^{1}$ JOHN C. BYATT, MICHAEL G. JENNINGS, PATRICIA G. \\ COMENS-KELLER, AND ROBERT J. COLLIER
}

Animal Sciences Division, Monsanto Company, St. Louis, Missouri 63198

\begin{abstract}
Total somatomedins from milk of bovine somatotropin-treated cows were isolated and characterized to determine the relative amount of the three amino acid N-terminally truncated form of IGF-I (destripeptide IGFI). The somatomedin fraction was isolated using organic solvent and solid-phase extractions followed by preparative reverse phase HPLC and affinity chromatography. The overall yield of IGF-I was $28 \%$, and destripeptide IGF-I was recovered with similar efficiency. The isolated somatomedins were resolved by capillary zonal electrophoresis and identified using recombinant somatomedin standards. The concentration of destripeptide IGF-I relative to full length IGF-I was determined by amino terminal sequencing and by bioassay. Results from these experiments indicated that the level of destripeptide IGF-I in milk from somatotropin-treated cows was less than $3 \%$ of the IGF-I concentration. Destripeptide IGF-I is therefore a minor component of the somatomedins present in milk from treated cows and does not contribute significantly to the proliferative activity of this milk. (Pediatr Res 32: 296-300, 1992)
\end{abstract}

\section{Abbreviations}

bST, bovine somatotropin

des IGF-I, destripeptide IGF-I

The insulin-like growth factors (or somatomedins) are a family of polypeptides that have structural similarity to proinsulin (1). Two principal somatomedins (IGF-I and IGF-II) have been identified in most species (2). These two molecules share approximately $62 \%$ sequence identity (3), but the primary amino acid sequence of each of the somatomedins has been highly conserved across species. Thus, the sequence of IGF-I is identical in humans and cattle (4) and the sequence of bovine IGF-II is $94 \%$ identical to the human molecule (5).

A variant of IGF-I that lacks the first three amino terminal residues (des IGF-I) was first isolated from bovine colostrum (6), where it comprises a major component (approximately 50\%) of the IGF-I fraction. The des IGF-I has 5- to 10-fold greater biologic activity than IGF-I in some in vitro bioassays (5-8). The increased potency of des IGF-I appears to be due to the fact that it is not bound by several of the IGF binding proteins (8-10). Because the sequence of des IGF-I is identical to IGF-I with the exception of the truncated amino terminus, it is not possible to distinguish between these two growth factors by existing assay methods (i.e. RIA). Consequently, very little is known about the tissue distribution, concentration, or biologic significance of des IGF-I.

Received January 31, 1992; accepted April 28, 1992.

Correspondence and reprint requests: John C. Byatt, Monsanto Company, 700 Chesterfield Parkway North, St. Louis, MO 63198.

'Present address: Amgen Inc., Thousand Oaks, CA 91320.
Both IGF-I and IGF-II are found in bovine milk $(11,12)$. The concentration of IGF-I is related to parity of the animal and stage of lactation $(13,14)$. Administration of bST elevates the blood plasma concentrations of IGF-I (15). The milk concentration of IGF-I is also increased by administration of bST (16), although this increase is typically within the range of concentrations found in milk from nontreated cattle (14).

Because milk from bST-treated cows has a slightly higher concentration of IGF-I, the oral activity of this growth factor has been tested. The data indicate that IGF-I has no oral activity (17, 18). Extensive data pertaining to the safety of milk from bSTtreated cows was also reviewed at a technology assessment conference convened by the National Institutes of Health. The review panel concluded that "meat and milk from bST-treated cows are as safe as those from untreated cows" (19). This same conclusion was restated in a commentary in the journal of the American Academy of Pediatrics (20). However, it has been assumed that the increase in IGF-I in milk was due to full length IGF-I. Given that RIA cannot differentiate between IGF-I and des IGF-I, it is possible that the concentration of the truncated molecule is elevated in milk from bST-treated cows. Because des IGF-I, under some circumstances, is more bioactive than IGF-I, there has been some reservation about the safety of milk in the absence of data on the concentration of des IGF-I (21). We have therefore developed a procedure to isolate somatomedins from milk and methods to directly and indirectly measure the relative concentration of des IGF-I in milk from cows treated with bST.

\section{MATERIALS AND METHODS}

Isolation of somatomedins. Somatomedins were isolated from $4 \mathrm{~L}$ of milk pooled from six bST-treated $(480 \mathrm{mg} / 2 \mathrm{wk})$ cows in mid lactation. These cows had received at least three injections of bST, and the milk was collected from d 7 of the treatment cycle. Initial extraction of IGF was similar to the method of Francis et al. (5). The milk was defatted by mixing with 0.3 volumes of 1,1,2-trichloro-1,2,2-trifluoroethane at $5^{\circ} \mathrm{C}$ for 15 $\mathrm{min}$ in a separatory funnel. The aqueous phase was mixed with an equal volume of ethanol: $12 \mathrm{M} \mathrm{HCl}(87.5: 12.5$, vol:vol $)$ at $5^{\circ} \mathrm{C}$ for $1 \mathrm{~h}$ using an Ultra Turrax (Virtis, Gardiner, NY) shear homogenizer equipped with a nonaerating mixer. Precipitated protein was removed by centrifugation $(27000 \times g$ for $15 \mathrm{~min}$ at $5^{\circ} \mathrm{C}$ ), and the supernatant was concentrated by vacuum rotary evaporation at $37^{\circ} \mathrm{C}$ to remove ethanol and most of the $\mathrm{HCl}$. The $\mathrm{pH}$ of the concentrated solution was adjusted to 3.0 with 2 $M$ sodium hydroxide and filtered $(0.45 \mu \mathrm{m}$ HT Tufryn membrane; Gelman, Ann Arbor, MI) to remove fine particulate material. Extracted IGF were adsorbed onto a column $(16 \times 5.5$ $\mathrm{cm}$ ) of Delta Pak C-18 (Waters, Milford, MA) and were eluted with a stepwise change in acetonitrile concentration (20 to $50 \%)$. The eluate was concentrated by vacuum evaporation and then applied to a reverse-phase HPLC column $(30 \times 2.8 \mathrm{~cm})$ of Asahipak ODP-90 (Keystone Scientific, Bellefonte, PA). Adsorbed material was eluted with a 25 to $45 \%$ acetonitrile gradient 
developed in 10-column volumes at a flow rate of $10 \mathrm{~mL} / \mathrm{min}$. The somatomedin-containing fraction was concentrated as before, then loaded onto a second reverse-phase HPLC column $(2.2 \times 25 \mathrm{~cm})$ of Vydac $218 \mathrm{TP}$ (Vydac, Hesperia, CA). Adsorbed material was eluted with a 25 to $35 \%$ acetonitrile gradient developed in 10-column volumes at a flow rate of $1 \mathrm{~mL} / \mathrm{min}$. The somatomedin-containing fraction was collected and concentrated as before.

IGF-I and des IGF-I in the somatomedin-enriched fraction were further purified by antibody affinity chromatography for amino terminal protein sequencing. A diethlyaminoethyl-Cibacron blue column (BioRad, Richmond, CA) was used to purify the Ig fraction from antiserum raised against bovine IGF-I. This antiserum had greater than $90 \%$ cross-reactivity with des IGF-I but less than $2 \%$ cross-reactivity with IGF-II. The Ig fraction was covalently coupled to a carbonyliimidazole-activated trisacryl resin (HW-65F) according to the manufacturer's instructions (Pierce, Rockford, IL). The solid phase immunoadsorption was carried out by adding to the sample an equal weight of affinity resin suspended in $0.1 \mathrm{M}$ sodium borate buffer, $\mathrm{pH}$ 8.5. This was then agitated on a roller mixer for $12 \mathrm{~h}$ at room temperature. The resin was sedimented by centrifugation $(10000 \times g$ for 10 s) and the supernatant was added to a fresh batch of resin exactly as before. The affinity resin from the second adsorption was combined with that from the first. Adsorbed solutes were eluted batchwise by the addition of one resin volume $6 \mathrm{M}$ guanidine hydrochloride and mixing for $1 \mathrm{~h}$ at room temperature. Resin was sedimented by centrifugation, as before, and then washed twice more with $6 \mathrm{M}$ guanidine hydrochloride. The three supernatants from this step were combined and dialyzed (1 000 molecular weight cut-off membrane) at $5^{\circ} \mathrm{C}$ for $24 \mathrm{~h}$ against three changes of water. Trace protein contaminants were removed by analytical reverse-phase HPLC $(0.46 \times 25 \mathrm{~cm}$ Vydac 218 TP54 column) using an elution gradient from 25 to $45 \%$ acetonitrile ( $1 \% / \mathrm{mL}$ per $\mathrm{min})$.

Somatomedin RIA. RIA for IGF-I and IGF-II were used to determine which fractions contained somatomedins during the purification steps. These assays were carried out essentially as described by Vicini et al. (22). Intra- and interassay coefficients of variation were 11.0 and $9.0 \%$ for the IGF-I assay and 9.1 and $15.1 \%$ for assay of IGF-II. Cross-reactivity of recombinant des IGF-I and recombinant N-methionyl des IGF-I with the antiserum used in the IGF-I RIA was greater than $90 \%$ for both variants. The acidified-ethanol extraction step was omitted for samples generated after acid-ethanol extraction of the milk because IGF binding proteins were undetectable by ligand blotting [method of Hossenlopp et al. (23)]. Organic solvent was removed from samples by vacuum desiccation at room temperature, and samples were reconstituted with RIA buffer.

Recovery of IGF-I and des IGF-I. Recombinant IGF-I (Monsanto lot D-17) and recombinant des IGF-I (N-methionyl des IGF-I:des IGF-I, 4:1; Monsanto lot JG-3) were radiolabeled with ${ }^{125}$ I using a lactoperoxidase procedure. The radioiodinated growth factors were individually added to a small volume of acid-ethanol extracted milk. These samples were run on small scale versions of the reverse-phase columns used to purify the somatomedins. We were therefore able to determine if the recovery of IGF-I and des IGF-I was equivalent for each of the reversephase purification steps.

Capillary zonal electrophoresis. A Beckman Pace 2000 capillary zonal electrophoresis system (Beckman, Fullerton, CA) was used to resolve IGF-I, IGF-II, and des IGF-I and to determine the relative concentrations of these molecules. An open tubular uncoated fused-silica capillary column, $50 \mathrm{~cm} \times 75 \mu \mathrm{m}$, was used with $0.2 \mathrm{M}$ sodium borate buffer, $\mathrm{pH} 11$. The electrophoresis was usually carried out at $15 \mathrm{kV}$ and $175 \mu \mathrm{A}$ for $30 \mathrm{~min}$ at $25^{\circ} \mathrm{C}$.

Amino terminal protein sequencing. Gas phase automated Edman degradation chemistry was used to determine amino terminal protein sequences through at least five amino acid residues and to determine the relative amount of each sequence. The sample was augmented with an internal standard of recombinant des IGF-I. The amino terminal residue of $80 \%$ of the standard was methionine. The remaining $20 \%$ of the standard had the same amino terminal sequence as native des IGF-I. An internal standard was included to check recovery of derivitized residues. Sample was applied to a Polybrene derivatized filter disk in several aliquots followed by drying and then sequencing. An Applied Biosystems, Inc. model 470A gas phase sequencer (Foster City, CA) was used for the degradations (24). The resulting phenylthiohydantoin amino acid derivatives were identified by reverse-phase HPLC in an on-line fashion using an Applied Biosystems, Inc. model 120A PTH analyzer fitted with a Brownlee (Foster City, CA) $2.1 \mathrm{~mm}$ inner diameter PTH-C18 column.

L6 myoblast proliferation assay. Proliferative activity of the somatomedin-enriched fraction was compared with activities of known amounts of standard recombinant IGF using the L6 myoblast bioassay. Proliferation of L6 myoblast cells is stimulated by des IGF-I, IGF-I, and IGF-II (25). This assay was conducted essentially according to the method of Kotts et al. (26). Briefly, the cells were plated at a density of $10^{3}$ cells $/ \mathrm{cm}^{2}$ on 24-well culture plates (Costar, Cambridge, MA) in Dulbecco's minimal essential medium plus $2 \%$ FCS. Twenty-four h after plating, the medium was removed and replaced with $1 \mathrm{~mL}$ Dulbecco's minimal essential medium plus $2 \%$ FCS containing IGF standards or the somatomedin-enriched fraction. Care was taken to remove organic solvents from samples before they were assayed. After $24 \mathrm{~h}$, the culture medium was replaced with fresh test medium and the cellswere incubated for an additional $48 \mathrm{~h}$. Cell number was estimated at the end of this period with a fluorometric assay for DNA (27). Each sample was assayed in triplicate wells and intraassay coefficient of variation was 4.1 to $9.8 \%$. Samples were assayed on three separate occasions and values shown are means $\pm \mathrm{SD}$. The recombinant somatomedin standards used in this assay were IGF-II (Monsanto lot JK-2), IGF-I (Monsanto lot D-17), and des IGF-I (N-methionyl des IGF-I:des IGF-I, 4:1; Monsanto lot JG-3). The bioactivity of Nmethionyl des IGF-I was equivalent to that of des IGF-I in this assay.

\section{RESULTS}

Somatomedin purification. The overall recovery of IGF-I in the somatomedin-enriched fraction was $28 \%$ by RIA (Table 1 ) with a $5 \times 10^{5}$-fold enrichment by volume. The recoveries of both IGF-I and des IGF-I were determined individually using radioiodinated material and scaled down versions of the reverse phase columns used in the purification process. Given that des IGF-I is inseparable from IGF-I by most chromatographic methods, it was assumed that both molecules would be purified with equal efficiency. Results from the recovery experiments (presented in Table 2) indicated that this was a valid assumption.

Capillary zonal electrophoresis. It was discovered that des IGFI could be separated from IGF-I and -II by capillary zonal electrophoresis. Recombinant standards of des IGF-I, IGF-I, and IGF-II were clearly resolved by this method (Fig. 1). Capillary zonal electrophoresis was therefore used to estimate the relative concentrations of IGF-I and des IGF-I in the somatomedinenriched fraction (Fig. 2, top panels). Peaks corresponding to IGF-I and IGF-II were identified by addition of recombinant IGF-I ( panel $A$ ) and IGF-II ( panel $B$ ) to the sample. There was also a small riding peak on the leading edge of the IGF-II peak that could have corresponded to des IGF-I. Recombinant des IGF-I standard added to the enriched fraction eluted in the vicinity of this peak ( panel $C$ ). However, retention time of the peak from added des IGF-I was not identical to that of the shoulder on the IGF-II peak. We were thus unable to provide clear evidence that this small peak in the somatomedin-enriched fraction was due to des IGF-I.

Amino terminal protein sequencing. We were unable to obtain 
Table 1. Milk somatomedin purification summary

\begin{tabular}{|c|c|c|c|c|}
\hline Purification step & $\begin{array}{l}\text { IGF-I concentration } \\
(\mathrm{ng} / \mathrm{mL})^{*}\end{array}$ & $\begin{array}{c}\text { Total volume } \\
(\mathrm{mL})\end{array}$ & $\begin{array}{c}\text { Total IGF-I } \\
(\mu \mathrm{g})\end{array}$ & Overall recovery $(\%)$ \\
\hline Milk & 9.9 & 4000 & 39.6 & \\
\hline $\mathrm{HCl} /$ ethanol extract & 5.9 & 8000 & 47.2 & 120 \\
\hline Concentrated extract & 50.7 & 800 & 40.5 & 102 \\
\hline Delta Pak load/rinse & 0.75 & 800 & 0.62 & 1.5 loss \\
\hline Delta Pak $20 \%$ eluate & Undetectable & 2000 & Undetectable & 0.0 loss \\
\hline Delta Pak $100 \%$ eluate & Undetectable & 2000 & Undetectable & 0.0 loss \\
\hline Delta Pak $50 \%$ eluate & 10.9 & 2000 & 21.7 & 55 \\
\hline $50 \%$ eluate concentrate & 30.2 & 700 & 21.1 & 53 \\
\hline Asahi Pak Prep HPLC & 14.8 & 1000 & 14.8 & 37 \\
\hline Vydac C18 Prep HPLC concentrate & 2800 & 4 & 11.04 & 28 \\
\hline
\end{tabular}

$*$ SI unit conversion $\times 0.1307$.

Table 2. Recovery of ${ }^{125} I-I G F-I$ and ${ }^{125} I$-des IGF-I from each of three reverse-phase steps carried out on small scale

\begin{tabular}{ccc}
\hline & \multicolumn{2}{c}{$\%$ Recovery } \\
\cline { 2 - 3 } Purification step & IGF-I & des IGF-I \\
\hline Delta Pak & 38 & 42 \\
Asahi Pak & 95 & 98 \\
Vydac C18 & 99 & 122 \\
\hline
\end{tabular}

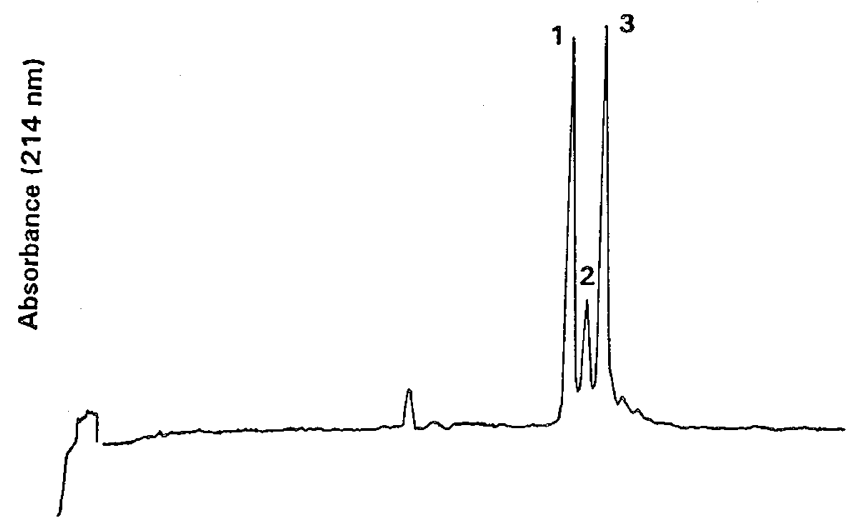

Fig. 1. Capillary zonal electrophoresis of recombinant somatomedin standards. Approximately $1 \mathrm{nmol}(8 \mathrm{ng}$ ) of IGF-I and des IGF-I and 0.33 $\mathrm{nmol}(2.5 \mathrm{ng})$ of IGF-II were injected. Peak 1 is des IGF-I, peak 2 is IGF-II, and peak 3 is IGF-I.

definitive evidence that des IGF-I was present in the somatomedin-enriched fraction by capillary zonal electrophoresis; therefore, a more direct means of identification and quantification was required. Amino terminal sequence analysis can be used to confirm identity and provide information on the relative concentrations of a mixture of two or three proteins. However, to obtain clear results with this method, the sample being sequenced should contain only the proteins of interest. Therefore, immunoaffinity chromatography was used to remove IGF-II and other unidentified protein contaminants in the somatomedin-enriched fraction. Recombinant des IGF-I ( $30 \mathrm{pmol} ; 230 \mathrm{ng}$ ) was added to the immunopurified IGF-I as an internal standard to check sequencing efficiency. The recombinant material was a 4:1 mixture N-methionyl des IGF-I:des IGF-I; thus, $80 \%$ of the standard could be differentiated from any native des IGF-I in the immunopurified sample. Results from amino terminal protein sequencing are shown in Table 3 . All of the relative molar yield of methionyl des IGF-I was from the internal standard. Assuming equal recovery of native des IGF-I and N-methionyl des IGF-I, then $6 \mathrm{pmol}$ of des IGF-I was from the recombinant internal standard and $6 \mathrm{pmol}$ originated from the enriched somatomedin fraction. If it is presumed that the ratio of full length IGF-I to des IGF-I in the immunopurified fraction is similar to that found in whole milk, then approximately $3 \%$ of the total IGF-I meas- ured by RIA would be due to des IGF-I. The concentration of IGF-I in the pooled milk used for this study was $1.3 \mathrm{nM}(9.9 \mathrm{ng} /$ $\mathrm{mL}$ ); therefore, the concentration of des IGF-I in the pooled milk was calculated to be approximately $0.04 \mathrm{nM}(0.3 \mathrm{ng} / \mathrm{mL})$.

L6 myoblast bioassay. Proliferation of L6 myoblasts is stimulated by all three of the somatomedins in a dose-responsive manner (Fig. 3). Des IGF-I was 3- to 5-fold more potent than IGF-I and IGF-I was about 4- to 6-fold more potent than IGFII. Des IGF-I is therefore a very potent mitogen in this bioassay. Proliferation stimulated by the somatomedin-enriched fraction was compared with the proliferation stimulated by a mixture of IGF-I and -II at the same concentration as present in the enriched fraction. Concentrations of IGF-I and IGF-II in the somatomedin-enriched fraction were determined by specific RIA. If a large proportion of the IGF-I measured by RIA was in fact des IGF-I, then the proliferation stimulated by the enriched fraction would be greater than that obtained with equivalent concentrations of IGF-I and IGF-II.

The somatomedin-enriched fraction stimulated a $149 \%$ increase in DNA. A mixture of recombinant IGF-I and IGF-II at equivalent concentrations as in the somatomedin fraction increased DNA by $152 \%$ in the same assay (Table 4 ).

\section{DISCUSSION}

A number of growth factors have been found in mammary secretions from the several species examined to date. The type of growth factors and the concentrations vary considerably depending on the species as well as stage of lactation. Epidermal growth factor is one of the major mitogenic factors found in human milk (28), but it is absent or undetectable in milk from cows and goats (29). Another class of growth factors found in human milk are the somatomedins; the concentration of IGF-I is in the range 0.77 to $1.03 \mathrm{nM}$ (6 to $8 \mathrm{ng} / \mathrm{mL}$ ) (30). Somatomedins are also found in ruminant milk $(11,12)$. In dairy cattle, the concentration of IGF-I in milk from commercial dairies averaged $0.55 \mathrm{nM}(4.3 \mathrm{ng} / \mathrm{mL})(14)$. Des IGF-I has been purified from bovine colostrum (5), but it was unknown whether this IGF-I variant was also found in milk or if the concentration was altered by treatment with somatotropin. Because there is no specific assay for des IGF-I, it was necessary to purify the somatomedins in milk so that they could be resolved by chromatography or by amino terminal sequence analysis.

Key to the measurement of des IGF-I in milk was the development of a purification procedure that could be used to isolate both IGF-I and des IGF-I with equal efficiency as well as with high overall recovery. The four-step procedure that was developed achieved these objectives, and sufficient material was isolated from $4 \mathrm{~L}$ of milk to estimate the relative concentration of des IGF-I. Des IGF-I and IGF-I display very similar chromatographic behavior; thus, it was difficult to fully resolve these two growth factors, even with analytical reverse-phase HPLC. However, baseline resolution of des IGF-I from IGF-I from IGF-II was achieved using capillary zonal electrophoresis. Furthermore, 


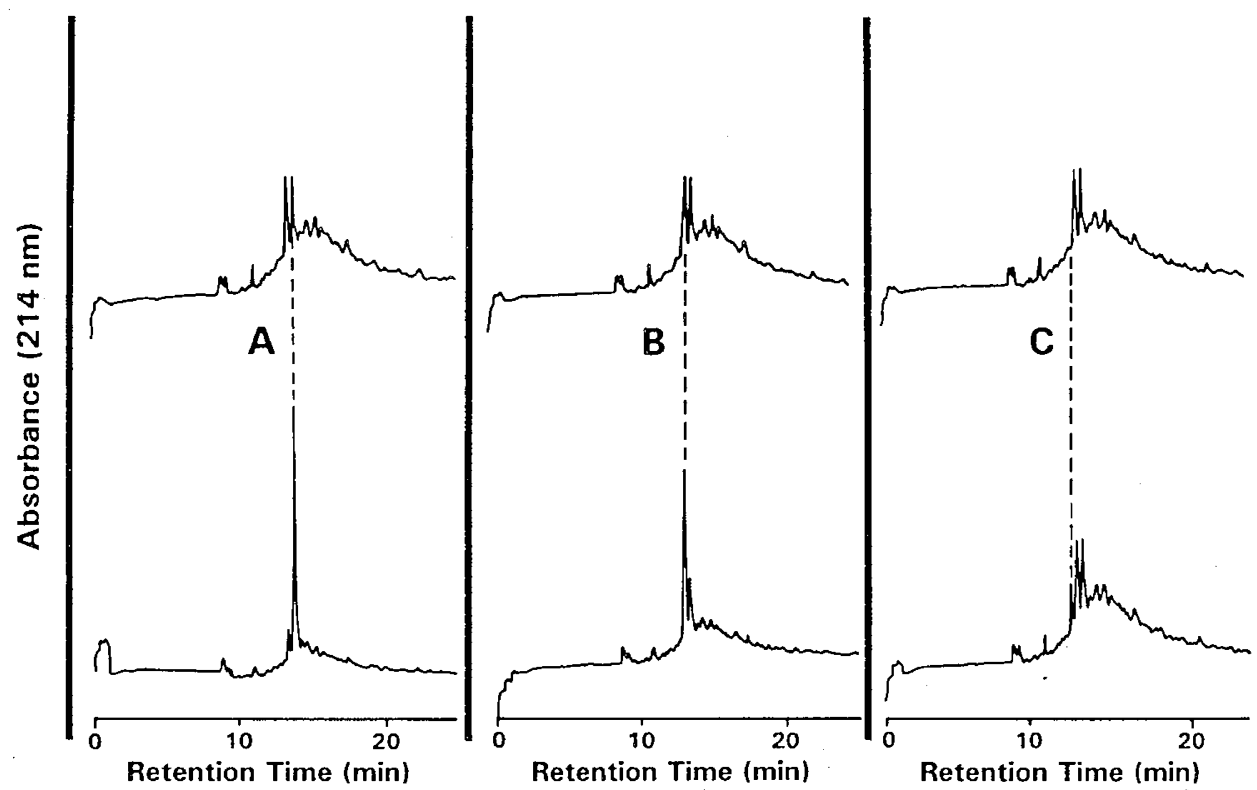

Fig. 2. Capillary zonal electrophoresis of the somatomedin-enriched fraction (top graphs). The bottom graphs are electropherograms of the same fraction after addition of recombinant IGF-I $(A)$, recombinant IGF-II $(B)$, and recombinant des IGF-I $(C)$. Approximately 0.75 to 1.5 nmol $(6$ to $12 \mathrm{ng}$ ) of each IGF standard was added to the somatomedin-enriched fraction.

Table 3. N-Terminal amino acid sequencing and quantitation of immunopurified IGF-I and des IGF-I

\begin{tabular}{|c|c|c|c|c|c|c|c|c|c|c|c|c|}
\hline Somatomedin & \multicolumn{12}{|c|}{ Designated sequences } \\
\hline \multirow{5}{*}{$\begin{array}{l}\text { IGF-I } \\
\text { des IGF-I (methionyl) } \\
\text { des IGF-I (native) }\end{array}$} & G & $\mathrm{P}$ & $\mathrm{E}$ & $\mathrm{T}$ & $\mathrm{L}$ & $\mathrm{x}$ & G & A & $E$ & $\mathrm{~L}$ & $\mathrm{~V}$ & $\mathrm{D} \ldots$ \\
\hline & & & M & $\mathrm{T}$ & $\mathrm{L}$ & $\mathrm{x}$ & $\mathrm{G}$ & A & $\mathrm{E}$ & $\mathrm{L}$ & $\mathrm{V}$ & D... \\
\hline & & & & $\mathrm{T}$ & $\mathrm{L}$ & $\mathrm{X}$ & $\mathrm{G}$ & A & $\mathrm{E}$ & $\mathrm{L}$ & $\mathrm{V}$ & $\mathrm{D} \ldots$ \\
\hline & \multicolumn{12}{|c|}{ Quantitation } \\
\hline & \multicolumn{4}{|c|}{$\begin{array}{l}\text { Initial yield } \\
(\mathrm{pmol})\end{array}$} & \multicolumn{6}{|c|}{$\begin{array}{l}\text { Average repetitive yield } \\
(\%)\end{array}$} & \multicolumn{2}{|r|}{ Relative molar \% } \\
\hline IGF-I & \multicolumn{4}{|c|}{216} & \multicolumn{6}{|c|}{94} & \multicolumn{2}{|r|}{86} \\
\hline des IGF-I (methionyl)* & \multicolumn{4}{|c|}{23} & \multicolumn{6}{|c|}{95} & \multicolumn{2}{|r|}{9} \\
\hline des IGF-I (native) $\dagger$ & \multicolumn{4}{|c|}{12} & \multicolumn{6}{|c|}{87} & & 5 \\
\hline
\end{tabular}

* All of the methionyl des IGF-I was from an internal standard ( $30 \mathrm{pmol})$ of recombinant material added to the immunopurified sample.

$\dagger$ Approximately $20 \%$ of the added recombinant standard had an identical $\mathrm{N}$-terminal amino acid sequence as native des IGF-I. Thus, 6 pmol of the native des IGF-I originated from the internal standard.

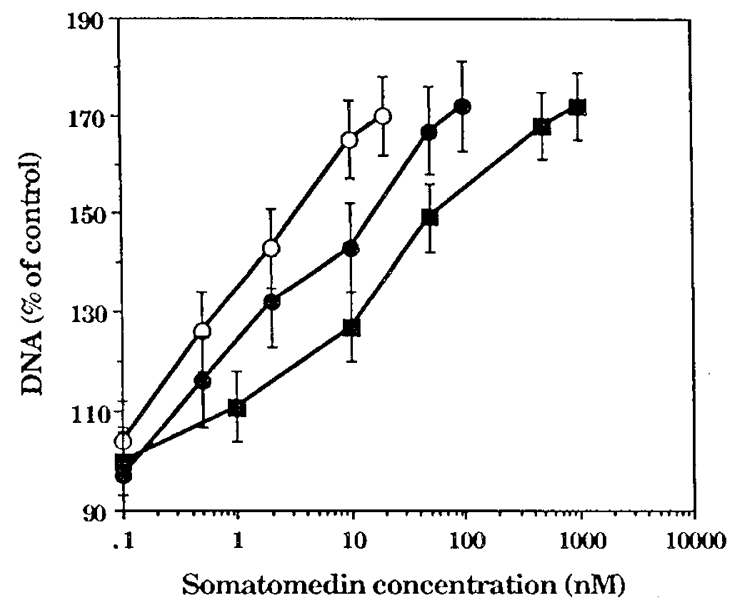

Fig. 3. Dose-response curves for des IGF-I (O), IGF-I $(\bullet)$, and IGFII (ם) in the L6 myoblast proliferation assay. Points are the means from three separate assays and error bars indicate SD.
Table 4. Activity of somatomedin-enriched fraction and mixture of IGF-I and IGF-II standards in L6 myoblast proliferation assay

\begin{tabular}{ccc}
\hline Sample & $\begin{array}{c}\text { Somatomedin } \\
\text { concentration* }\end{array}$ & $\begin{array}{c}\text { Activity } \\
\text { (\% of control) }\end{array}$ \\
\hline Somatomedin fraction $\dagger$ & 5.7 nM IGF-I & 149 \\
& 65 nM IGF-II & \\
IGF-I + IGF-II standards $\ddagger$ & 5.7 nM IGF-I & 152 \\
& $65 \mathrm{nM}$ IGF-II & \\
\hline
\end{tabular}

* The somatomedin fraction and the mixture of standards were added to the culture medium so that the final concentrations were 10 -fold lower than shown in the table.

$\dagger$ Concentrations of IGF-I and IGF-II in the somatomedin fraction measured by RIA.

$\ddagger$ Concentration of the somatomedin standards was determined by amino acid analysis.

this method was sufficiently sensitive to detect ng quantities of somatomedins. Analysis of the somatomedin-enriched fraction by this electrophoretic method demonstrated the presence of IGF-I and IGF-II, but it was unclear if a minor peak with approximately the same retention time as recombinant des IGFI standard was in fact due to des IGF-I. The area of the putative des IGF-I peak was approximately $5 \%$ of the IGF-I peak area, 
suggesting that, if des IGF-I was present in the somatomedinenriched fraction, it was a minor component.

Amino terminal protein sequencing was used as a more direct determination of whether des IGF-I was present in the somatomedin-enriched fraction. Immunoaffinity adsorption was used to ensure that IGF-I and des IGF-I were the major components in the fraction to be sequenced. Inclusion of an internal standard of recombinant methionyl des IGF-I enabled us to determine that the recombinant standard was recovered with equal efficiency as full-length IGF-I. The sequence analysis also indicated that des IGF-I was a minor component of the somatomedin fraction and that it was present at approximately $3 \%$ of the concentration of IGF-I.

The L6 myoblast proliferation bioassay was used as a qualitative assessment as to whether des IGF-I was present in the somatomedin-enriched fraction. Des IGF-I stimulates half maximal proliferation at a concentration of about $1 \mathrm{nM}$ and is the most potent somatomedin in the L6 bioassay (Fig. 2). However, a combination of IGF-I and IGF-II appeared to account for all of the proliferative activity present in the enriched fraction. Even though IGF-II is about $1 / 4$ to $1 / 6$ as potent as IGF-I (in the L6 myoblast assay) the majority of the IGF-mediated proliferative activity in milk is probably due to IGF-II because it is present at approximately a 10 -fold higher concentration than IGF-I. The bioassay results also suggest that, if des IGF-I is present in milk, it has a negligible contribution to proliferative activity.

Although it would be preferable to measure des IGF-I concentrations by a direct and specific method, such an assay does not presently exist. The somatomedins in milk were purified and concentrated several thousand-fold, and the methods used to detect des IGF-I were not strictly quantitative. Therefore, it is difficult to precisely calculate the concentration of des IGF-I in the original pooled milk sample. However, we demonstrated that IGF-I and des IGF-I were recovered from each of the purification steps with equal efficiency and that des IGF-I was present in the somatomedin-enriched fraction at no more than $3 \%$ of the IGFI concentration. The concentration of IGF-I in the pooled raw milk sample was $1.3 \mathrm{nM}(9.9 \mathrm{ng} / \mathrm{mL})$, suggesting that the concentration of des IGF-I in the milk was approximately $0.04 \mathrm{nM}$ $(0.3 \mathrm{ng} / \mathrm{mL})$. Furthermore, all of the IGF-mediated proliferative activity in milk of bST-treated cattle could be accounted for by the full-length IGF-I and IGF-II present.

The question arises as to why the concentration of des IGF-I is very much higher in bovine colostrum than milk. There is insufficient data available to provide a definitive answer, but we speculate that the level of des IGF-I may be related to control of mammary growth. Des IGF-I is a more potent stimulator of bovine mammary epithelial cell proliferation than IGF-I (31). Thus, mammary production of des IGF-I may be increased during pregnancy to help stimulate mammogenesis. Conversely, local production of des IGF-I would be greatly decreased during lactation when there is little proliferation of mammary epithelium.

Acknowledgment. The authors thank Terri Whitehead for carrying out the somatomedin radioimmunoassays.

\section{REFERENCES}

1. Zapf J, Froesch ER 1986 Insulin-like growth factors/somatomedins: structure, secretion, biological activity and physiological role. Hormone Res 24:121130

2. Holly JMP, Wass JAH 1989 Insulin-like growth factors: autocrine, paracrine or endocrine? New perspectives of the somatomedin hypothesis in the light of recent developments. J Endocrinol 122:611-618

3. Humbel RE 1984 Insulin-like growth factors, somatomedins and multiplication stimulating activity. I. Chemistry. In: Li CH (ed) Hormonal Proteins and Peptides, Vol 12. Academic Press, New York, pp 57-81
4. Honegger A, Humbel RE 1986 Insulin-like growth factors I and II in fetal and adult bovine serum: purification, primary structures and immunological cross-reactivities. J Biol Chem 261:569-575

5. Francis GL, Upton FM, Ballard FJ, McNeil HA, Wallace JC 1988 Insulin-like growth factors I and II in bovine colostrum. Sequences and biological activities compared with those of a potent truncated form. Biochem $\mathbf{J}$ 251:95-103

6. Francis GL, Read LC, Ballard FJ, Bagley CJ, Upton FM, Gravestock PM, Wallace JC 1986 Purification and partial sequence analysis of insulin-like growth factor-I from bovine colostrum. Biochem J 233:207-213

7. Ballard FJ, Francis GL, Ross M, Bagley CJ, May B, Wallace JC 1987 Natural and synthetic forms of insulin-like growth factor-I (IGF-I) and the potent derivative, destripeptide IGF-I: biological activities and receptor binding. Biochem Biophys Res Commun 149:398-404

8. Ballard FJ, Francis GL, Bagley CJ, Szabo L, Wallace JC 1989 Effects of insulinlike growth factors on protein metabolism: why are some molecular variants more potent? Biochem Soc Symp 55:91-104

9. Ross M, Francis GL, Szabo L, Wallace JC, Ballard FJ 1989 Insulin-like growth factor (IGF) binding proteins inhibit the biological activities of IGF-I and IGF-II but not des-(1-3)-IGF-I. Biochem J 258:267-272

10. Simes JM, Wallace JC, Walton PE 1991 The effects of insulin-like growth factor-I (IGF-I), IGF-II and des(1-3)IGF-I, a potent IGF analogue, on growth hormone and IGF-binding protein secretion from cultured rat anterior pituitary cells. J Endocrinol 130:93-99

11. Malven PV, Head HH, Collier RJ, Buonomo FC 1987 Periparturient changes in secretion and mammary uptake of insulin and in concentrations of insulin and insulin-like growth factors in milk of dairy cows. J Dairy Sci 70:22542265

12. Ronge H, Blum JW 1988 Somatomedin C and other hormones in dairy cows around parturition, in newborn calves and in milk. J Anim Physiol Anim Nutr 60:168-176

13. Campbell PG, Baumrucker CR 1989 Insulin-like growth factor-I and its association with binding proteins in bovine milk. J Endocrinol 120:21-29

14. Collier RJ, Miller MA, Hildebrandt JR, Torkelson AR, White TC, Madsen KS, Vicini JL, Eppard PJ, Lanza GM 1991 Factors affecting insulin-like growth factor-I concentration in bovine milk. J Dairy Sci 74:2905-2911

15. Cohick WS, Plaut K, Sechen SJ, Bauman DE 1989 Temporal pattern of insulin-like growth factor-I response to exogenous bovine somatotropin in lactating cows. Domest Anim Endocrinol 6:263-274

16. Prosser CG, Fleet IR, Corps AN 1989 Increased secretion of insulin-like growth factor-I into milk of cows treated with recombinant derived bovine growth hormone. J Dairy Res 56:17-26

17. Hammond BG, Collier RJ, Miller MA, McGrath MF, Hartzeli DL, Kotts CE, Vandaele W 1990 Food safety and pharmacokinetic studies which support a zero meat and milk withdrawal time for use of sometribove in dairy cows. Ann Rech Vet 21:107s-120s

18. Juskevich JC, Guyer CG 1990 Bovine growth hormone: human food safety evaluation. Science 249:875-884

19. NIH Technology Assessment Conference statement on bovine somatotropin 1991 JAMA 265:1423-1425

20. Kretchmer N 1991 Why not have more milk? Pediatrics 88:1056-1057

21. Mepham TB 1991 Bovine somatotropin and public health: need for further independent and more extensive investigation. Br Med J 302:483-484

22. Vicini JL, Buonomo FC, Veenhuizen JJ, Miller MA, Clemmons DR, Collier RJ 1991 Effects of nutritional balance and stage of lactation in dairy cows on insulin, insulin-like growth factors I and II and insulin-like growth factor binding protein 2 responses to somatotropin administration. J Nutr 121:1656-1663

23. Hossenlopp P, Seurin D, Segovia-Quinson B, Hardouin S, Binoux M 1986 Analysis of serum insulin-like growth factor binding proteins using western blotting: use of the method for titration of the binding proteins and competitive binding studies. Anal Biochem 154:138-143

24. Hunkapiller MW, Hewick RM, Dreyer RJ, Hood LE 1983 High sensitivity sequencing with a gas-phase sequencer. Methods Enzymol 91:399-406

25. Konishi Y, Kotts CE, Bullock LD, Tou JS, Johnson DA 1989 Fragments of insulin-like growth factors I and II stimulate proliferation of rat L6 myoblast cells. Biochemistry 28:8872-8877

26. Kotts CE, White ME, Allen CE, Martin F, Dayton WR 1987 A statistically standardized muscle cell culture bioassay measuring the effect of swine serum on muscle cell proliferation. J Anim Sci 64:615-622

27. Kissane JM, Robins E 1958 The fluorometric measurement of deoxyribonucleic acid in animal tissue with special reference to the central nervous system. J Biol Chem 233:184-188

28. Shing YW, Klagsbrun M 1984 Human and bovine milk contain different sets of growth factors. Endocrinology 115:273-282

29. Brown $\mathrm{KD}$, Blakeley DM 1983 Cell growth promoting-activity in mammary secretions of the goat, cow and sheep. Br Vet J 139:68-78

30. Baxter RC, Zaltsman Z, Turtle JR 1984 Immunoreactive somatomedin-C/ insulin-like growth factor-I and its binding protein in human milk. $\mathrm{J}$ Clin Endocrinol Metab 58:955-959

31. McGrath MF, Collier RJ, Clemmons DR, Busby WH, Sweeny CA, Krivi GG 1991 The direct in vitro effect of insulin-like growth factors (IGFs) on normal bovine mammary cell proliferation and production of IGF binding proteins. Endocrinology 129:671-678 